\title{
Effect of Guava (Psidium guajava) Leaves Essential Oil on Some Reproductive Parameters in Male Guinea Pig (Cavia porcellus)
}

Ngoula Ferdinand $^{1 *}$, Nouboudem S Christiane ${ }^{1}$, Kenfack Augustave ${ }^{1}$, Tadondjou C D'Alex ${ }^{1}$, Kana J Raphael ${ }^{1}$, Kouam Jean-Marc ${ }^{1}$, Tsafack Borice $^{1}$, Ngoumtsop V Herman ${ }^{1}$, Nguemdjo T Maryvone ${ }^{1}$, Akassa Herman $^{1}$, Ousmane Issa Abdel Djalil', Kamtchouing Pierre ${ }^{2}$, Marco Galeotti ${ }^{3}$ and Tchoumboue Joseph ${ }^{1}$

${ }^{1}$ Department of Animal Science, Faculty of Agronomy and Agricultural Sciences, University of Dschang, Cameroon

${ }^{2}$ Department of Animal Biology and Physiology, Faculty of Sciences, University of Yaounde I, Cameroon

${ }^{3}$ Sezione di Patologia Veterinaria, Dipartimento di Scienze degli Alimenti, Università degli Studi di Udine, Via Sondrio, 233100 Udine, Italy

\begin{abstract}
Aim: To assess the effects of essential oill from guava leaves on some reproductive parameters.

Methods: Thirty-two male guinea pigs (Cavia porcelus) of three months old and weighing between 350 and $400 \mathrm{~g}$ were used. These guinea pigs were divided into 4 groups of 8 animals each. Each group was randomly attributed orally for 60 days one of the following guava leaf essential oil doses: 0 (control group), 80, 100 and $120 \mu \mathrm{l}$ of oil per kg body weight. At the end of treatment, all animals were sacrificed to assess the reproductive parameters.

Results: Body weight, relative weight of the seminal vesicles, vas deferens, and epididymis were not significantly increased $(p>0.05)$ with the considered guava leaves essential oil doses. The testes weights significantly increased $(p<0.05)$ in animals who received 100 and $120 \mu \mathrm{l} / \mathrm{kg}$ body weight compared to control. A significant increase $(p<0.05)$ in sperm concentration, mobility and viability was observed in animals which received the essential oil doses compared to control. Also, the level of proteins and testosterone in serum and testes significantly increased $(p<0.05)$ with the essential oil doses.
\end{abstract}

Conclusion: Guava leaves essential oil can be used to improve male reproductive performances.

Keywords: Essential oil; Guava leaves; Male reproductive system; Guinea pig

\section{Introduction}

Essential oil (or sometimes vegetable gas) is the concentrate and hydrophobic liquid of volatile aromatic compounds (odoriferous) of a plant. It is specific to seed coniferous plants and is found in the families of Labiatae and Myrtaceae [1]. Although the essential oils have some common points in their modes of action, their properties are varied: they are anti-infectious, antifungal, antiparasitic, antibacterial, antiinflammatory, etc. These properties are used in animal production $[1,2]$.

Guava (Psidium guajava) is a fruit tree of the family of Myrtaceae, native from South America and growing in the tropics. All parts (roots, fruits, leaves, etc.) are used in traditional medicine for the treatment of diseases such as gastrointestinal and respiratory disorders, diabetes, cancer, etc. [3-5]. Studies on extracts from the leaves of P. guajava and essential oil they contain showed that they possess anti-inflammatory, antibiotics, analgesics, hepato protective and antioxidant activities [6$8]$.

Many studies have been conducted in the field of animal production; on the effects of essential oils on growth performance [9-12], but very little information exist regarding their effects on reproductive performances. Experimental studies showed that in rats treated with leaves extracts from Psidium guajava, there was an increase in the levels of reproductive hormones (testosterone, LH, FSH), of testes and epididymis weight, of mobility and epididymal sperm concentration [13-16]. Although these studies showed some positive effects of guava leaves extracts on reproductive performances, no studies on the effects of its essential oil on these parameters have been performed. Thus the main objective of this work was to determine the effects of guava leaves essential oil on some reproduction parameters in male guinea pig.

\section{Materials and Methods}

\section{Plant material and essential oil extraction}

Fresh guava leaves were collected from the Dschang University campus, dried in the shade and then crushed. Oil extraction was done by hydrodistillation in the Laboratory of Animal Physiology of the Faculty of Agronomy and Agricultural Sciences. After separation, the oil was filtered through anhydrous sodium sulphate to remove any trace of water.

\section{Animal material}

Thirty-two (32) males guinea pigs (Cavia porcellus) aged 3 months old and weighing between 350 and $400 \mathrm{~g}$, all reproduced at the Teaching and Research Farm of the University of Dschang were used for testing.

\section{Experimental design}

The animals were randomly divided into 4 groups and maintained in 4 identical boxes. For 60 days, animals in box 1 (control) received orally distilled water $(1 \mathrm{ml} / \mathrm{kg}$ body weight), while the other three test groups during this same time, received respectively by gavage 80,100 and $120 \mu \mathrm{l}$ per kg body weight of guava leaves essential oil. Throughout

*Corresponding author: Ngoula Ferdinand, Department of Animal Science, Faculty of Agronomy and Agricultural Sciences, University of Dschang, Cameroon, Tel.: +237 75125443; E-mail: fngoula@yahoo.fr

Received May 14, 2014; Accepted June 28, 2014; Published June 30, 2014

Citation: Ferdinand N, Christiane NS, Augustave K, D'Alex TC, Raphael KJ et al. (2014) Effect of Guava (Psidium guajava) Leaves Essential Oil on Some Reproductive Parameters in Male Guinea Pig (Cavia porcellus). Biol Syst Open Access 3: 125. doi:10.4172/2329-6577.1000125

Copyright: (c) 2014 Ferdinand N, et al. This is an open-access article distributed under the terms of the Creative Commons Attribution License, which permits unrestricted use, distribution, and reproduction in any medium, provided the original author and source are credited. 


\begin{tabular}{|c|c|}
\hline Ingredients & Amount $(\mathbf{k g} / \mathbf{1 0 0 k g})$ \\
\hline Corn & 20,00 \\
\hline Bran wheat & 39,50 \\
\hline Palm kernel cake & 15,00 \\
\hline Cotton seed meal & 8,00 \\
\hline Soybean meal & 3,00 \\
\hline Fishmeal & 1,00 \\
\hline Bone meal & 1,00 \\
\hline Premix 10\% & 2,00 \\
\hline Salt & 0,50 \\
\hline Pennisetum purpurum & 10,00 \\
\hline Total & 100 \\
\hline Metabolizable energy (Kcal/Kg) & 2014,5 \\
\hline Crude protein (\%) & 17.72 \\
\hline Crude fiber (\%) & 12.11 \\
\hline Calcium (\%) & 1.15 \\
\hline Phosphorus (\%) & 0.87 \\
\hline
\end{tabular}

Table 1: centesimal composition and bromatological characteristics of the ration.

the experimental period, feed (Table 1) and water were provided ad libitum to animals.

\section{Serum and organs collections}

At the end of treatment, blood was collected by heart puncture from each guinea pig under etheranesthesia. Serum was isolated and stored at $-20^{\circ} \mathrm{C}$ prior to analysis.

After killing the guinea pigs by overdose of ether, organs including testes, epididymis, vas deferens and seminal vesicles were carefully removed, rid of adipose tissue, blotted dry and weighed separately. The left testis was then homogenized in a known volume of cold distilled water, and aliquots of supernatant were kept at $-20^{\circ} \mathrm{C}$ prior to biochemical estimations.

\section{Sperm density and motility}

Immediately after the sacrifice, the right epididymis of each animal was minced in $10 \mathrm{ml}$ of warm $\left(36^{\circ}\right) \mathrm{NaCl}$ solution for motility evaluation. $20 \mu \mathrm{l}$ of this mixture were used to count motile and nonmotile sperms (X 40). The percentage of motile spermatozoa was determined using the following formula:

Percentage of mobile spermatozoa $=[$ Number of mobile spermatozoa/Total number of counted spermatozoa] X 100

The sperm density was determined in the right cauda epididimis using a Thoma haemocytometer.

\section{Biochemical analysis}

Total protein contents of serum and testes were determined using the methods of Biuret [17] and Bradford [18] respectively. Serum and intra-testicular total testosterone were determined using a commercial kit (ELISA AccuDiag ${ }^{\mathrm{TM}}$, Diagnostic Automation Inc).

\section{Statistical analysis}

Data were submitted to ANOVA test at $\mathrm{P}<0.05$. When differences were significant between means, the latter were separated using the Duncan test. The analyses were performed using SPSS 20.0.

\section{Results}

\section{Body and reproductive organs weight}

As shown in Table 2, the essential oil had no effect on the body weight of the animals. the relative testicular weight was significantly increased $(p<0.05)$ but the relative epididymal weight, seminal vesicles weight as well as vas deferens weight were not significantly increased with the doses of guava leaves essential oil $(\mathrm{p}>0.05)$.

\section{Sperm characteristics}

Administration of guava leaves essential oil for 60 days significantly increased the epididymal sperm count dose-dependently compared to the control group. Also, mobility and viability increased as the essential oil dose increased. Except for sperm motility, the values of sperm characteristics parameters were significantly higher $(p<0.05)$ with the highest dose compared to the lowest dose of essential oil (Table 3 ).

\section{Biochemical parameters}

It also comes out from Table 3 that the serum and testicular proteins increased significantly with essential oil dose. When compared to control, the values obtained in groups that received essential oil were significantly higher $(\mathrm{p}<0.05)$. Elevated testosterone levels were observed in guinea pigs treated with the essential oil. Between treated groups, testosterone levels were significantly higher with the highest dose $(120 \mu \mathrm{l} / \mathrm{kg}$ body weight).

\section{Discussion}

The findings of the study indicate that guava leaves essential oil induces an increase in weights of sexual organs such as testis, epididymis, seminal vesicles and vas deferent dose-dependently. These results are comparable to those found by Woode et al. [19] in male rats treated with ethanol extract of the fruits of Xylopia aethiopica at doses 30,100 and $300 \mathrm{mg} / \mathrm{kg}$ bw; Ekaluo et al. $[15,16]$ in rats treated with aqueous extracts of Psidium guajava leaves (0, 100, 200 and $300 \mathrm{mg} /$ $\mathrm{kg} \mathrm{bw}$ ), and Farouk et al. [20] in male rats treated with essential oil of Syzygium aromaticum $(0,1 \mathrm{mg} / \mathrm{kg} \mathrm{bw})$. The weight, size and secretory function of testes, epididymis and seminal vesicle are closely regulated by androgens [21]. In fact, Androgens, especially testosterone have anabolic properties which are characterized by an increased synthesis of proteins and therefore muscle mass. Androgens then contribute to the increased volume and weight of the testis and epididymis by

\begin{tabular}{|c|c|c|c|c|}
\hline \multirow{2}{*}{ parameters } & \multicolumn{4}{|c|}{ essential oil Doses ( $\mu \mathrm{l} / \mathrm{kg}$ body weight) } \\
\hline & 0 (control) $(n=8)$ & $80(n=8)$ & $100(n=8)$ & $120(n=8)$ \\
\hline Final body weight (g) & $408.51 \pm 21.18^{a}$ & $411.03 \pm 22.62^{\mathrm{a}}$ & $411.76 \pm 22.27^{\mathrm{a}}$ & $412.60 \pm 33.74^{\mathrm{a}}$ \\
\hline \multicolumn{5}{|c|}{ Organ weights (g/100 g bw) } \\
\hline Testes & $0.17 \pm 0.01^{\mathrm{a}}$ & $0.18 \pm 0.05^{\mathrm{a}}$ & $0.22 \pm 0.4^{\mathrm{ab}}$ & $0.25 \pm 0.05^{b}$ \\
\hline epididymis & $0.038 \pm 0.004^{a}$ & $0.039 \pm 0.018^{a}$ & $0.039 \pm 0.011^{\mathrm{a}}$ & $0.044 \pm 0.008^{\mathrm{a}}$ \\
\hline Seminal vesicles & $0.20 \pm 0.1^{\mathrm{a}}$ & $0.24 \pm 0.1^{\mathrm{a}}$ & $0.25 \pm 0.2^{\mathrm{a}}$ & $0.32 \pm 0.2^{\mathrm{a}}$ \\
\hline vas deferens & $0.042 \pm 0.008^{a}$ & $0.043 \pm 0.010^{\mathrm{a}}$ & $0.046 \pm 0.024^{a}$ & $0.049 \pm 0.010^{\mathrm{a}}$ \\
\hline
\end{tabular}

$(a, b)$ On the same line, values affected by the same letter were not significantly different $(p>0.05) ; n=$ number of guinea pigs; Values are presented as Means \pm SD.

Table 2: Effect of guava leaves essential oil on the final body weight and the relative weight of the reproductive organs. 


\begin{tabular}{|c|c|c|c|c|}
\hline \multirow{2}{*}{ paramètres } & \multicolumn{4}{|c|}{ essential oil doses ( $\mu \mathrm{l} / \mathrm{kg}$ body weight) } \\
\hline & 0 (control) $(n=8)$ & $80(n=8)$ & $100(n=8)$ & $120(n=8)$ \\
\hline \multicolumn{5}{|l|}{ Sperm characteristics } \\
\hline \multicolumn{5}{|l|}{ Sperm density $\left(\times 10^{6}\right)$} \\
\hline Per cauda epididymis & $149.85 \pm 5.07^{a}$ & $151.50 \pm 4.52^{\mathrm{a}}$ & $156.16 \pm 4.68^{b}$ & $15877 \pm 6.26^{\mathrm{b}}$ \\
\hline per gram of tissue & $447.53 \pm 18.20^{a}$ & $454.5 \pm 20.56^{a}$ & $471.65 \pm 22.57^{b}$ & $476.30 \pm 19.71^{b}$ \\
\hline Mobility (\%) & $89.54 \pm 5.15^{\mathrm{a}}$ & $91.68 \pm 4.59^{\mathrm{ab}}$ & $93.07 \pm 3.21^{\mathrm{ab}}$ & $94.75 \pm 1.93^{b}$ \\
\hline Viability (\%) & $90.72 \pm 3.16^{a}$ & $91.89 \pm 3.59^{a}$ & $92.01 \pm 2.57^{\mathrm{a}}$ & $95.08 \pm 1.39^{b}$ \\
\hline \multicolumn{5}{|l|}{ Biochemical parameters } \\
\hline Serum proteins $(\mathrm{mg} / \mathrm{ml})$ & $11.54 \pm 3.53^{a}$ & $16.43 \pm 4.62^{\mathrm{a}}$ & $18.14 \pm 4.60^{b}$ & $18.20 \pm 5.7^{\mathrm{b}}$ \\
\hline Testicular protein $(\mu \mathrm{g} / \mathrm{g})$ & $718.7 \pm 225.19^{a}$ & $94511 \pm 106.77^{b}$ & $1157.09 \pm 115.82^{c}$ & $1317.72 \pm 71.80^{\circ}$ \\
\hline Serum testosterone $(\mathrm{ng} / \mathrm{ml})$ & $2.31 \pm 0.36^{\mathrm{a}}$ & $4.15 \pm 0.30^{\mathrm{b}}$ & $4.46 \pm 0.29^{b}$ & $5.08 \pm 0.23^{c}$ \\
\hline Testicular testosterone $(\mathrm{ng} / \mathrm{g})$ & $3.80 \pm 0.70^{a}$ & $4.38 \pm 0.46^{a}$ & $6.05 \pm 0.53^{b}$ & $7.61 \pm 0.55^{c}$ \\
\hline
\end{tabular}

$(a, b)$ On the same line, values affected by the same letter were not significantly different $(p>0.05) . n=$ number of guinea pigs; Values are presented as Means \pm SD.

Table 3: Effects of guava leaves essential oil on sperm characteristics and biochemical parameters.

stimulating protein synthesis $[21,22]$. The present study showed a significant increase in serum and testicular protein in guinea pigs which received the essential oil of guava leaves. This increase could be the result of the action of testosterone [23]. The increase in these organs weight could be due to an increase in androgens production. As showed in our study, the essential oil of Psidium guajava induced a significant increase in serum and testicular testosterone in treated animals compared to control. This oil may stimulate the synthesis of testosterone by acting on the hypothalamic-pituitary-testicular axis. However, since Uboh et al. [13,14] reported that aqueous extracts of Psidium guajava have no effect on $\mathrm{LH}$ and FSH production. A direct stimulatory effect of essential oil of Psidium guajava on steroidogenesis in leydig cells could be suggested.

This work also revealed a significant increase of epididymal sperm concentration in treated groups. This result could be explained by the elevation of testosterone level. Testosterone is the main male gonadal hormone produced by Leydig cells in the testes in response to LH and under the control of the hypothalamic-pituitary axis [24]. A certain concentration of this hormone is necessary for the initiation and maintenance of spermatogenesis and for stimulating the growth and functioning of the prostate and seminal vesicles [25]. Moreover, it has been reported that the increase in both the sperm concentration and the weight of sexual organs is an indicator of improving male fertility [19]. Sherines et al. [26] showed that the size of the testis is the first evaluation criterion of spermatogenesis because the seminiferous tubules and germinal elements constitute about $98 \%$ of the total mass of the testis. Thus, the significant increase in the weight of the testes in guinea pigs that received the essential oil is also related to an increase of sperm production. This observation is similar to those of Akinola et al. [27] and Cajuday and Pocsidio [28] in rats and mice, respectively, treated with aqueous extracts of Psidium guajava and Moringa oleifera.

The guava leaves essential oil treatment also resulted in a dosedependent increase in mobility and sperm viability. These results corroborated the findings of Akinola et al. [27] and Uboh et al. [13,14] who reported similar effect of aqueous extract of Psidium guajava in rats. This increase can be attributed to the antioxidant properties of the Psidium guajava leaves essential oil. In fact, the sperm membrane is rich in polyunsaturated fatty acids, making them especially susceptible to reactive oxygen species (ROS) derived from oxygen metabolism. In addition to an action on lipids, the ROS may also damage DNA and proteins [29]. These molecules can cause lipid peroxidation of the sperm plasma membrane, damage to the structure of the axoneme, problems in the course of capacitation or the acrosome reaction, and loss of motility, which can lead to infertility [30]. However, the essential oil from the leaves of guava contains a number of compounds (phenolic compounds) which confer antioxidant properties, and which would act as scavengers of free radicals [31-33], thus limiting their negative consequences on sperm.

In conclusion, the essential oil from Psidium guajava leaves stimulates the production of testosterone, boost sperm production and improve the viability and motility of sperm. Therefore, it can be advised for use by male to improve the reproductive performance.

\section{Competing Interest}

The authors declare that they have no competing interest.

\section{Author's Contributions}

NF, NS, KA, KP and TJ contributed substantially to conception and design of the study, data analysis and interpretation. NS, TB, NH, NM contributed in data acquisition. NF, NS, TC, KE contributed in drafting the article or revising it critically for important intellectual content. All the authors read and approved the final manuscript.

\section{References}

1. Recoquillay F (2009) L'intérêt des huiles essentielles. 9e Journée Productions porcines et avicoles.

2. Konstantopoulou I, Vassilopoulou L, Mavragani-Tsipidou P, Scouras ZG (1992) Insecticidal effects of essential oils. A study of the effects of essential oils extracted from eleven Greek aromatic plants on Drosophiliaauraria. Experientia 48: $616-619$

3. Oh WK, Lee CH, Lee MS, Bae EY, Sohn CB (2005) Antidiabetic effects of extracts from Psidium guajava. J Ethnopharmacol 93: 411-415.

4. Shen SC, Cheng FC, Wu NJ (2008) Effect of guava (Psidium guajava Linn) leaf soluble solids on glucose metabolism in type 2 diabetic rats. Phytother Res 22:1458-1464.

5. Rai PK, Jaiswal D, Mehta S, Wathal G (2009) Anti-hyperglycaemic potential of Psidium guajava raw fruit peel. Indian J Med Res 129: 561-565.

6. Hawrelak J (2003) Medicinal herb monograph: Guava (Psidium guajava). J AustTradit-Med Soc 9: 25-29.

7. Roy CK, Kamath JV, Asad M (2006) Hepatoprotective activity of Psidium guajava Linn leaf extract. Indian J Exp Biol 44: 305-311.

8. Ryu NH, Park KR, Kim SM, Yun HM, Nam D (2012) A Hexane Fraction of Guava Leaves (Psidium guajava L.) Induces Anticancer Activity by Suppressing AKT/ Mammalian Target of Rapamycin/Ribosomal p70 S6 Kinase in Human Prostate Cancer Cells. J Med Food 15: 231-24.

9. Hernandez F, Madrid J, Garcia V, Orengo J, Megias MD (2004) Influence of two plant extracts on broilers performance, digestibility, and digestive organ size. Poul Sci 83: 169-174.

10. Benchaar, Chaves AV, Fraser GR, Wang Y, Beauchemin KA, Mc-Allister TA 
Citation: Ferdinand N, Christiane NS, Augustave K, D'Alex TC, Raphael KJ, et al. (2014) Effect of Guava (Psidium guajava) Leaves Essential Oil on Some Reproductive Parameters in Male Guinea Pig (Cavia porcellus). Biol Syst Open Access 3: 125. doi:10.4172/2329-6577.1000125

Page 4 of 4

(2007) Effects of essential oils and their components on in vitro rumen microbial fermentation. Canadian Journal of Animal Science 87: 413-419.

11. Jang IS, Ko YH, Kang SY, Lee CY (2007) Effect of a commercial essential oil on growth performance, digestive enzyme activity and intestinal microflora population in broiler chickens. Anim Feed Sci Technol 134: 304-315.

12. Mathlouthi N, Bouzaïenne T, Oueslati, Recoquillay F, Hamdi M, Bergaoui R (2009) he effect of two essential-oil preparations on in vitro of bacterial growth and performances of broiler chickens.

13. Uboh FE, Edet EE, Eteng MU, Eyong EU (2010 $)$ Comparative effect of aqueous extract of $P$. guajava and ascorbic acid on serum sex hormones levels in male and female rats. Journal of Applied Science and Research 6: 275-279.

14. Uboh FE, Iniobong E, Okon, Moses BE $\left(2010^{b}\right)$ Effect of Aqueous Extract of Psidium Guajava Leaves on Liver Enzymes, Histological Integrity and Hematological Indices in Rats. Gastroenterology Research 3: 32-38.

15. Ekaluo UB, Erem FA, Omeje IS, Ikpeme EV, Ibiang YB, et al. (2013ª) Aqueous leaf extract of guava: a non-toxic male fertility booster. Journal of Environmental Science, Toxicology and Food Technology 3: 21-23.

16. Ekaluo UB, Erem FA, Omeje IS, Ikpeme EV, Ibiang YB, et al. (2013b) Is aqueous leaf extract of guava spermatotoxic in rat? Journal of Environmental Science, Toxicology and Food Technology 3: 21-23.

17. Gornal AG, Bardwil GS, David MM (1949 $)$ Determination of serum proteins by mean of Biuret reactions. J Biol Chem 177: 751-766.

18. Bradford MN (1976) A rapid and sensitive method for the quantification of microgram quantity of protein-dye binding. Anal Biochem 72: 248-254.

19. Woode E, Alhassan A, Chrissie S, Abaidoo (2011) Effect of ethanolic fruit extract of Xylopia aethiopica on reproductive function of male rats. Int J Pharm Biomed Res 2: 161-165.

20. Farouk B, Abdelkrim B, Malika B-S, Badreddine AK, Djallel EH, et al. (2013) Ameliorative Effects of Syzygium aromaticum Essential Oil on Fertility in Male Rats Exposed to Manganese. Advances in Sexual Medicine 3: 85-91.

21. Hazard J, Perlemuter L, Yves Abramovici, Muriel Bourgeon (2000) Endocrinologie. Masson, Paris, 484p.
22. Gayrard V (2007) Physiologie de la reproduction des mammifères. Ecole Nationale Vétérinaire, Toulouse 198p.

23. Gupta RS, Kachhawa JB, Chaudhary R (2004) Antifertility effects of methanolic pod extract of Albizzialebbeck. Asian Journal of Andrology 6: 155-159.

24. Chauhan NS, Rao ChV, Dixit VK (2007) Effect of Curculigo orchioides rhizomes on sexual behavior of male rats. Fitoterapia 78: 530-534.

25. Chauhan NS, Dixit VK (2010) Effects of Bryonia laciniosa seeds on sexual behavior of male rats. Int J Impot Res 22: 190-195.

26. Sherines RJ, Howards SS (1978) Male infertility. In: Harrison JH, Gittes RF Perimutter AD, Stamey TA, Walsh PC, eds. Campbell's Urology. 4th ed. Philadelphia, Pa: W.B. Saunders Co 715p

27. Akinola OB, Oladosu OS, Dosumu OO (2007) Spermatoprotective activity of the leaf extract of $P$. guajava Linn. Niger Postgrad Med J 14: 273-276.

28. Cajuday LA, Poscidio GL (2010) Effects of Moringa oleifera Lam (Morigaceae) on the receptor coactivators. Review of Neuroscience 16: 339-357.

29. Grignard E (2005) Analyse de protéines spermatiques post-testiculaires, et développement d'outils pour le contrôle de la fertilité de différents mammifères: Equuscaballus, Bostaurus, Arvicolaterrestris Scherman. Thèse de PhD Université Blaise Pascal 178p.

30. Tramer F, Rocco F, Micali F, Sandri G, Panfili E (1998) Antioxidant systems in rat epididymal spermatozoa. Biol Reprod 59: 753-758.

31. Chen HY, Yen GC (2007) Antioxidant activity and free radical-scavenging capacity of extracts from guava (Psidium guajava L.) leaves. Food Chemistry 101: 686-694.

32. Knasmüller S, Nersesyan A, Misík M, Gerner C, Mikulits W, et al. (2008) Use of conventional and -omics based methods for health claims of dietary antioxidants: a critical overview. Br J Nutr 99: ES3-52.

33. Metwally AM, Omar AA, Harraz FM, El Sohafy SM (2010) Phytochemical investigation and antimicrobial activity of Psidium guajava $L$. leaves. Pharmacogn Mag 6: 212-218. 